\title{
Induction of Somatic Embryogenesis from Cocoa Farmer Field Collection of ICT - Peru
}

\author{
Mar Asunción Gárate-Navarro and Enrique Arévalo-Gardini * \\ Instituto de Cultivos Tropicales (ICT). Av. Ahuashiyacu S/N, Cuadra 16, Sector Laguna Venecia, \\ Banda del Shilcayo, Tarapoto, San Martín, Perú. \\ * Corresponding author email: enriquearevaloga@gmail.com
}

Received: 24 May 2017 / Accepted: 06 June 2017 / Published: 30 June 2017

\begin{abstract}
To induce the formation of embryogenic structures from staminodes, in 10 cocoa genotypes (Theobroma cacao L.) from the ICT Collection, the influence of the combination of two growth hormones $(2,4$ Dichlorophenoxyacetic 2,4 -D and Thidiazuron TDZ) was studied. Floral explants (staminodes), were induced to form calli in a culture medium supplemented with modified DKW mineral salts. At 12 days of implantation in the culture medium, the explants responded to the callus induction with a bulge at the base, covering the explants totally with callus at 40 days of culture. Embryogenic expression was shown at 52 days of culture. The genotypes ICT-2161 and ICT-2142 shows the highest percentage of somatic embryogenesis. Four types of callus, fine crystalline, thick crystalline, semi-compact and compact were observed. In addition, a clear organogenic response was observed when roots were formed from the callus generated.
\end{abstract}

Keywords: Tissue culture, tropical crops, in vitro propagation, micro propagation

\section{$1 \quad$ Introduction}

Sowing cacao for sexual seeds results in populations that are unproductive due to genetic segregation [1]. This has forced the search for propagation systems that guarantee the genetic stability of plantations with characteristics of high productivity and resistance to main diseases. Somatic embryogenesis has been successfully established from floral explants to regeneration of cocoa plants [2]. Somatic embryogenesis contributes to improve the cocoa multiplication system, since it is able to maintain the genetic uniformity of elite genotypes, allows clones to be obtained with a normal architecture and a radical system of great anchorage, besides other potentials that this technique presents for crop genetic improvement, exchange and conservation of plant material [3].

The degree of effectiveness of the currently available techniques of cocoa propagation (bud grafting and rooting) is variable depending on the environmental conditions, the mother plant and the graft, and the diseases that could affect during stalling [4], so the improvement of the vegetative propagation systems of this species is of great importance. However, somatic embryogenesis in cacao has behaved as recalcitrant because of the low levels of response that has been achieved and high variability in the different genotypes [5]. 
Induction of Somatic Embryogenesis from Cocoa Farmer Field Collection of ICT - Peru

Growth regulators are determinants of the embryogenic response as they interact with endogenous hormone levels and, in some cases, responses are given by the joint action of two or more regulators [2]. Based on this, the effect of the combination of two growth regulators 2,4-D and TDZ on the formation of calli and somatic embryos in 10 cocoa genotypes of the ICT Collection was studied.

\section{Materials and Methods}

\subsection{Location and Genotypes}

The study was carried out at the Vegetable Tissue Culture Laboratory of the Instituto de Cultivos Tropicales - ICT. 10 cacao genotypes from the ICT Collection (Table 1), located in the germplasm bank of the El Choclino Experimental Station of ICT. The genotypes were selected according to morphological and phytopatological studies due to their high productivity, tolerance to the main diseases of the crop, considering them as elite cacaos.

Table 1: Promising genotypes selected for their productive characteristics and resistance to diseases

\begin{tabular}{|l|l|l|}
\hline Genotypes & $\begin{array}{c}\text { Yield } \\
\text { kg/ha }\end{array}$ & \multicolumn{1}{|c|}{ Characteristics } \\
\hline ICT -1087 & 1596 & Black Pod Resistant \\
\hline ICT -1189 & 1388 & High productivity \\
\hline ICT -2171 & 1365 & High productivity \\
\hline ICT -1292 & 1203 & High productivity \\
\hline ICT - 2161 & 1156 & High productivity \\
\hline ICT -1092 & 1134 & High productivity \\
\hline ICT -1561 & 1134 & High productivity \\
\hline ICT -2175 & 1110 & High productivity \\
\hline ICT -1187 & 1041 & Frosty Pod Rot Resistant \\
\hline ICT -2142 & 1041 & High productivity \\
\hline
\end{tabular}

\subsection{Collection and Preparation of Explants}

The explants consisted of immature (closed) flowers of 3-4 $\mathrm{mm}$ in lengths, that were separated from the peduncle to extract the staminodes, and these were induced to express calli.

\subsection{Culture Media}

To induce callus in staminodes of the 10 genotypes studied, PCG (Primary Callus Growth), described in the Guiltinan and
Maximova protocol [6], and was used as a means of induction. The PCG medium was composed of mineral salts, DKW [7], vitamins and growth regulating hormones of 2,4Dichlorophenoxyacetic-2,4 D in two concentrations $\left(1,50 \mathrm{mg} \mathrm{l}^{-1}\right.$ and $\left.2,5 \mathrm{mg} \mathrm{l}^{-1}\right)$ combined with Thidiazuron-TDZ $\left(5.0 \mu \mathrm{g} \mathrm{l}^{-1}\right.$ and $\left.7.5 \mu \mathrm{g} \mathrm{l}^{-1}\right)$. For the formation of secondary callus, SCG (Secondary Callus Growth) based on WPM mineral salts [8] was used, using $0.15 \mathrm{mg} \mathrm{l}^{-1}$ Kinetin-KIN and $0.05 \mathrm{mg}$ 1-Benzylaminopurine-BAP; As in the previous case the method was modified by doing the same for the rest of culture media. Callus was sub cultured in ED (Embryo Development) culture medium composed of DKW mineral salts, adding 10\% coconut liquid endosperm as an organic component, using this medium until the expression of somatic embryos. The somatic embryos were cultured the PEC medium (Primary Embryo Conversion) without the presence of amino acids. All culture media were autoclaved at $121^{\circ} \mathrm{C}, 15$ pounds pressure for 20 minutes, immediately dispensed into 100x15 mm plates, performing this action one day prior to transfer. Subcultures were performed every 20 days.

\subsection{Sowing of Explants and Callus Induction}

Once collected the immature flowers were transferred to the Plant Tissue Culture Laboratory of ICT, rinsed with sterile distilled water (ADE), and sterilized with $1.5 \%$ sodium hypochlorite for 20 minutes with slow stirring and several rinses with ADE to remove the disinfectant residues. Using a scalpel blade the immature flowers were cut at the base near the junction with the peduncle to extract the staminodes, which were placed in contact with the surface of the culture medium indicated for each stage, finally incubated in the dark until the expression of somatic embryos; the methodology described is the one used in the laboratory.

\subsection{Callus Characterization}

The callus was characterized using the LEICA Zoom 2000 stereomicroscope, using the callus typology observed by Chanatásig (2004), which 
Gárate-Navarro et al., Int. Ann. Sci.; Vol. 2 Issue 1, pp: 6-11, 2017

mentions four types of callus: CCf $=$ fine crystalline callus, $\mathrm{CCg}=$ coarse crystalline callus, CSc $=$ semi-compact callus and $\mathrm{CC}=$ compact callus. The percentage of embryos and calli produced from the total number of explants cultivated, represent the embryogenic and callogenic frequency, respectively. The number of primary embryos produced by staminodes was evaluated at 60 days of induction.

\subsection{Statistical Analysis}

The statistical design used was Random Complete design, with factorial arrangement $10 \mathrm{x}$ 2 x 2 (10 genotypes, 2 Hormones and 2 hormonal doses), with 4 replicates per treatment. Statistical analysis of all variables was performed using the Scott \& Knott Test $(\mathrm{P}<0.05)$, using Infostat Ver. 2014 [9].

\section{Results and Discussion}

\subsection{Staminodes (RE)}

At 12 days old, the crop began the growth of the calli in explants, mostly in basal area. Table 2 show the high significative difference for genotypes and the interaction between genotype and 2.4 D. The best results for calli formation was observed at 40 days of the beginning of the crop in ICT-1087 and ICT-1187 genotypes with 1,50 mg 1-1 2.4-D and 7.50 $\mu$ g 1-1 TDZ, with an average of $97,50 \%$ and $91,88 \%$ respectively (Table 3). In the present study, at 40 days old the calli had covered the whole explants, this results were higher that the obtained by Quimbita [10], that reported calli formation at 40 days with $32 \%$. Urrea [2], used PCG and INDI media culture for calli induction, obtaining an average higher than $90 \%$ at 30 days.

\subsection{Calli Type (CT)}

Interaction between genotype and $2.4 \mathrm{D}$ use, show significative differences $(\mathrm{P}<0.05)$ between the characterized calli (Table 2 ). The type of calli observed in higher proportion was the fine crystalline, reaching an average between 12.5 and $92.5 \%$ (Table 3). The statistical analysis also reports significative differences for the type of semicompact calli, compact and thick crystalline calli. Not all explants had the capacity of forming a determined type of calli; therefore, finding different types and distinct proportions. The types of calli formed are in concordance with the ones reported by Chanatásig [11].

Quimbita [10], points out the importance of 2.4D for calli formation, obtaining creme color, friable and nodular calli, that shows their embryogenic characteristics, in correlation with the calli formation in the present experiment.

\subsection{Organogenic Responses (OR)}

At 38 days old, the crop, showed a strong organogenic modification, that had a friable, cream and brown colour appearance, some ramified with abundant root hairs, like the results showed by Santana et al [12]. Nevertheless, Díaz et al [13], reported in Eucalyptus organogenic modification at 35 days, with formation of roots in the calli, of white colour crystalline and compact, long, ramified, translucid and turgid formations. In previous assays (data not shown), root formation was obtained from 30 days, this could be due several factors such as genotype, media culture, among others. ANOVA shows high significance difference for genotypes and their interaction with the evaluated hormones (Table 2). The genotypes that showed the higher response were ICT-1292 and ICT-2161 with average of $92,50 \%$ y $88,75 \%$ respectively (Table 3).

Table 2: Analysis of variance (ANOVA) for the genotype and hormonal doses evaluated for calli formation. Cf = Fine Crystalline, $C g=$ Thick crystalline, $S c=$ Semi-compact y $C=$ Compact, $R E=$ Response to staminodes $y$ $R O=$ Organogenic response.

\begin{tabular}{|c|c|c|c|c|c|c|c|}
\hline \multirow{2}{*}{ Source of Variation } & \multirow{2}{*}{ DF } & \multirow{2}{*}{ RE $(\%)$} & \multicolumn{4}{|c|}{ Type of Calli (\%) } & \multirow{2}{*}{$\begin{array}{l}\text { RO } \\
(\%)\end{array}$} \\
\hline & & & $\mathbf{C f}$ & $\mathrm{Cg}$ & Sc & $\mathbf{C}$ & \\
\hline Genotype & 9 & $1409.7 * *$ & $2729.24 * *$ & $1192.29 * *$ & $2946.94 * *$ & $1144.79 * *$ & $10289.17 * *$ \\
\hline Genotype*2.4D & 9 & $830.83 * *$ & $1293.68 * *$ & $497.85 * *$ & $837.22 * *$ & $1653.13 * *$ & $2752.5 * *$ \\
\hline Genotype*TDZ & 9 & $209.44^{\mathrm{ns}}$ & $718.68^{\text {ns }}$ & $200.63^{\text {ns }}$ & $510^{\mathrm{ns}}$ & $720.9^{\mathrm{ns}}$ & $2165.28 *$ \\
\hline Genotype*2.4D*TDZ & 9 & $165^{\mathrm{ns}}$ & $654.24^{\mathrm{ns}}$ & $141.74^{\mathrm{ns}}$ & $253.06^{\mathrm{ns}}$ & $1282.01^{\mathrm{ns}}$ & $1808.61 *$ \\
\hline Experimental error & 117 & & & & & & \\
\hline Total & 153 & & & & & & \\
\hline
\end{tabular}


Induction of Somatic Embryogenesis from Cocoa Farmer Field Collection of ICT - Peru

Table 3: Interaction of genotypes (Factor A) and hormonal doses (Factor B), assessed for calli formation: Cf = Fine Crystalline, $C g=$ Thick Crystalline, $S c=$ Semi-compact, $C=$ Compact, $S R=$ Staminode response, OR=Organogenic response.

\begin{tabular}{|c|c|c|c|c|c|c|c|c|}
\hline \multirow[t]{2}{*}{ Genotypes } & \multicolumn{2}{|c|}{ Hormones } & \multirow[t]{2}{*}{ SR (\%) } & \multicolumn{4}{|c|}{ Type of Calli (\%) } & \multirow[t]{2}{*}{ OR (\%) } \\
\hline & $2.4 \mathrm{D}$ & TDZ & & $\mathrm{Cf}$ & $\mathrm{Cg}$ & Sc & $\mathrm{C}$ & \\
\hline \multirow[t]{4}{*}{ ICT-1087 } & \multirow[t]{2}{*}{1.50} & 5.00 & $95.00 \mathrm{a}$ & $87.50 \mathrm{a}$ & $12.50 \mathrm{~b}$ & $35.00 \mathrm{~b}$ & $37.50 \mathrm{c}$ & $32.50 \mathrm{~b}$ \\
\hline & & 7.50 & $100.00 \mathrm{a}$ & $82.50 \mathrm{a}$ & $12.50 \mathrm{~b}$ & $40.00 \mathrm{~b}$ & $40.00 \mathrm{c}$ & $35.00 \mathrm{~b}$ \\
\hline & \multirow[t]{2}{*}{2.50} & 5.00 & $100.00 \mathrm{a}$ & $92.50 \mathrm{a}$ & $15.00 \mathrm{~b}$ & $20.00 \mathrm{~b}$ & $25.00 \mathrm{c}$ & $37.50 \mathrm{~b}$ \\
\hline & & 7.50 & $95.00 \mathrm{a}$ & $65.00 \mathrm{a}$ & $10.00 \mathrm{~b}$ & $25.00 \mathrm{~b}$ & $52.50 \mathrm{~b}$ & $25.00 \mathrm{~b}$ \\
\hline \multirow[t]{4}{*}{ ICT-1092 } & \multirow[t]{2}{*}{1.50} & 5.00 & $90.00 \mathrm{a}$ & $50.00 \mathrm{~b}$ & $42.50 \mathrm{a}$ & $17.50 \mathrm{~b}$ & $40.00 \mathrm{c}$ & $55.00 \mathrm{~b}$ \\
\hline & & 7.50 & $77.50 \mathrm{a}$ & $17.50 \mathrm{~b}$ & $40.00 \mathrm{a}$ & $20.00 \mathrm{~b}$ & $35.00 \mathrm{c}$ & $32.50 \mathrm{~b}$ \\
\hline & \multirow[t]{2}{*}{2.50} & 5.00 & $65.00 \mathrm{~b}$ & $40.00 \mathrm{~b}$ & $12.50 \mathrm{~b}$ & $30.00 \mathrm{~b}$ & $25.00 \mathrm{c}$ & $55.00 \mathrm{~b}$ \\
\hline & & 7.50 & $82.50 \mathrm{a}$ & $52.50 \mathrm{a}$ & $27.50 \mathrm{a}$ & $12.50 \mathrm{~b}$ & $20.00 \mathrm{c}$ & $55.00 \mathrm{~b}$ \\
\hline \multirow[t]{4}{*}{ ICT-1187 } & \multirow[t]{2}{*}{1.50} & 5.00 & $100.00 \mathrm{a}$ & $65.00 \mathrm{a}$ & $12.50 \mathrm{~b}$ & $17.50 \mathrm{~b}$ & $30.00 \mathrm{c}$ & $57.50 \mathrm{~b}$ \\
\hline & & 7.50 & $100.00 \mathrm{a}$ & $75.00 \mathrm{a}$ & $10.00 \mathrm{~b}$ & $20.00 \mathrm{~b}$ & $27.50 \mathrm{c}$ & $50.00 \mathrm{~b}$ \\
\hline & \multirow[t]{2}{*}{2.50} & 5.00 & $80.00 \mathrm{a}$ & $65.00 \mathrm{a}$ & $15.00 \mathrm{~b}$ & $20.00 \mathrm{~b}$ & $25.00 \mathrm{c}$ & $22.50 \mathrm{~b}$ \\
\hline & & 7.50 & $87.50 \mathrm{a}$ & $67.50 \mathrm{a}$ & $10.00 \mathrm{~b}$ & $27.50 \mathrm{~b}$ & $37.50 \mathrm{c}$ & $32.50 \mathrm{~b}$ \\
\hline \multirow[t]{4}{*}{ ICT-1189 } & \multirow[t]{2}{*}{1.50} & 5.00 & $90.00 \mathrm{a}$ & $80.00 \mathrm{a}$ & $15.00 \mathrm{~b}$ & $27.50 \mathrm{~b}$ & $10.00 \mathrm{c}$ & $40.00 \mathrm{~b}$ \\
\hline & & 7.50 & $77.50 \mathrm{a}$ & $67.50 \mathrm{a}$ & $10.00 \mathrm{~b}$ & $35.00 \mathrm{~b}$ & $20.00 \mathrm{c}$ & $32.50 \mathrm{~b}$ \\
\hline & \multirow[t]{2}{*}{2.50} & 5.00 & $65.00 \mathrm{~b}$ & $57.50 \mathrm{a}$ & $12.50 \mathrm{~b}$ & $22.50 \mathrm{~b}$ & $27.50 \mathrm{c}$ & $75.00 \mathrm{a}$ \\
\hline & & 7.50 & $62.50 \mathrm{~b}$ & $55.00 \mathrm{a}$ & $10.00 \mathrm{~b}$ & $32.50 \mathrm{~b}$ & $15.00 \mathrm{c}$ & $12.50 \mathrm{~b}$ \\
\hline \multirow[t]{4}{*}{ ICT-1292 } & \multirow[t]{2}{*}{1.50} & 5.00 & $100.00 \mathrm{a}$ & $70.00 \mathrm{a}$ & $15.00 \mathrm{~b}$ & $77.50 \mathrm{a}$ & $10.00 \mathrm{c}$ & $95.00 \mathrm{a}$ \\
\hline & & 7.50 & $87.50 \mathrm{a}$ & $47.50 \mathrm{~b}$ & $15.00 \mathrm{~b}$ & $55.00 \mathrm{a}$ & $20.00 \mathrm{c}$ & $97.50 \mathrm{a}$ \\
\hline & \multirow[t]{2}{*}{2.50} & 5.00 & $87.50 \mathrm{a}$ & $35.00 \mathrm{~b}$ & $25.00 \mathrm{a}$ & $55.00 \mathrm{a}$ & $40.00 \mathrm{c}$ & $77.50 \mathrm{a}$ \\
\hline & & 7.50 & $85.00 \mathrm{a}$ & $32.50 \mathrm{~b}$ & $25.00 \mathrm{a}$ & $40.00 \mathrm{~b}$ & $67.50 \mathrm{~b}$ & $100.00 \mathrm{a}$ \\
\hline \multirow[t]{4}{*}{ ICT-1561 } & \multirow[t]{2}{*}{1.50} & 5.00 & $97.50 \mathrm{a}$ & $62.50 \mathrm{a}$ & $35.00 \mathrm{a}$ & $32.50 \mathrm{~b}$ & $35.00 \mathrm{c}$ & $15.00 \mathrm{~b}$ \\
\hline & & 7.50 & $92.50 \mathrm{a}$ & $65.00 \mathrm{a}$ & $40.00 \mathrm{a}$ & $15.00 \mathrm{~b}$ & $15.00 \mathrm{c}$ & $22.50 \mathrm{~b}$ \\
\hline & \multirow[t]{2}{*}{2.50} & 5.00 & $87.50 \mathrm{a}$ & $65.00 \mathrm{a}$ & $22.50 \mathrm{~b}$ & $22.50 \mathrm{~b}$ & $32.50 \mathrm{c}$ & $10.00 \mathrm{~b}$ \\
\hline & & 7.50 & $87.50 \mathrm{a}$ & $40.00 \mathrm{~b}$ & $35.00 \mathrm{a}$ & $30.00 \mathrm{~b}$ & $37.50 \mathrm{c}$ & $25.00 \mathrm{~b}$ \\
\hline \multirow[t]{4}{*}{ ICT-2142 } & 1.50 & 5.00 & $100.00 \mathrm{a}$ & $45.00 \mathrm{~b}$ & $25.00 \mathrm{a}$ & $17.50 \mathrm{~b}$ & $32.50 \mathrm{c}$ & $92.50 \mathrm{a}$ \\
\hline & & 7.50 & $90.00 \mathrm{a}$ & $12.50 \mathrm{~b}$ & $15.00 \mathrm{~b}$ & $10.00 \mathrm{~b}$ & $90.00 \mathrm{a}$ & $10.00 \mathrm{~b}$ \\
\hline & 2.50 & 5.00 & $85.00 \mathrm{a}$ & $52.50 \mathrm{a}$ & $27.50 \mathrm{a}$ & $15.00 \mathrm{~b}$ & $55.00 \mathrm{~b}$ & $10.00 \mathrm{~b}$ \\
\hline & & 7.50 & $92.50 \mathrm{a}$ & $62.50 \mathrm{a}$ & $27.50 \mathrm{a}$ & $20.00 \mathrm{~b}$ & $20.00 \mathrm{c}$ & $10.00 \mathrm{~b}$ \\
\hline ICT-2161 & 1.50 & 5.00 & $97.50 \mathrm{a}$ & $62.50 \mathrm{a}$ & $27.50 \mathrm{a}$ & $50.00 \mathrm{a}$ & $12.50 \mathrm{c}$ & $100.00 \mathrm{a}$ \\
\hline & & 7.50 & $92.50 \mathrm{a}$ & $55.00 \mathrm{a}$ & $22.50 \mathrm{~b}$ & $30.00 \mathrm{~b}$ & $32.50 \mathrm{c}$ & $77.50 \mathrm{a}$ \\
\hline & 2.50 & 5.00 & $92.50 \mathrm{a}$ & $55.00 \mathrm{a}$ & $45.00 \mathrm{a}$ & $30.00 \mathrm{~b}$ & $22.50 \mathrm{c}$ & $77.50 \mathrm{a}$ \\
\hline & & 7.50 & $100.00 \mathrm{a}$ & $55.00 \mathrm{a}$ & $30.00 \mathrm{a}$ & $27.50 \mathrm{~b}$ & $27.50 \mathrm{c}$ & $100.00 \mathrm{a}$ \\
\hline ICT-2171 & 1.50 & 5.00 & $87.50 \mathrm{a}$ & $37.50 \mathrm{~b}$ & $10.00 \mathrm{~b}$ & $22.50 \mathrm{~b}$ & $57.50 \mathrm{~b}$ & $77.50 \mathrm{a}$ \\
\hline & & 7.50 & $97.50 \mathrm{a}$ & $65.00 \mathrm{a}$ & $10.00 \mathrm{~b}$ & $52.50 \mathrm{a}$ & $40.00 \mathrm{c}$ & $75.00 \mathrm{a}$ \\
\hline & 2.50 & 5.00 & $77.50 \mathrm{a}$ & $35.00 \mathrm{~b}$ & $15.00 \mathrm{~b}$ & $65.00 \mathrm{a}$ & $12.50 \mathrm{c}$ & $35.00 \mathrm{~b}$ \\
\hline & & 7.50 & $90.00 \mathrm{a}$ & $45.00 \mathrm{~b}$ & $15.00 \mathrm{~b}$ & $70.00 \mathrm{a}$ & $15.00 \mathrm{c}$ & $97.50 \mathrm{a}$ \\
\hline ICT-2175 & 1.50 & 5.00 & $42.50 \mathrm{~b}$ & $27.50 \mathrm{~b}$ & $42.50 \mathrm{a}$ & $10.00 \mathrm{~b}$ & $47.50 \mathrm{~b}$ & $10.00 \mathrm{~b}$ \\
\hline & & 7.50 & $65.00 \mathrm{~b}$ & $52.50 \mathrm{a}$ & $10.00 \mathrm{~b}$ & $27.50 \mathrm{~b}$ & $17.50 \mathrm{c}$ & $67.50 \mathrm{a}$ \\
\hline & 2.50 & 5.00 & $82.50 \mathrm{a}$ & $57.50 \mathrm{a}$ & $10.00 \mathrm{~b}$ & $30.00 \mathrm{~b}$ & $50.00 \mathrm{~b}$ & $95.00 \mathrm{a}$ \\
\hline & & 7.50 & $90.00 \mathrm{a}$ & $75.00 \mathrm{a}$ & $10.00 \mathrm{~b}$ & $37.50 \mathrm{~b}$ & $30.00 \mathrm{c}$ & $87.50 \mathrm{a}$ \\
\hline
\end{tabular}

${ }^{a}$ Values with different letters are statistically different according to Scott-Knott $(\mathrm{p}<0,05)$. 


\subsection{Somatic Embryogenesis (SE)}

All the explants had the capacity of forming calli in vitro, however, not all possess the capacity of generating embryogenic calli [11]. Each of the cacao genotypes has different responses to the formation of calli and the somatic embryogenesis due genetic factor (Figure1), where interaction of media culture and type of explant produces specific results [3]-[11]-[14]-[15]. Statistical analysis reports that ICT-2161 and ICT-2142 genotypes, using $1.50 \mathrm{mg} \mathrm{l}^{-1} 2.4 \mathrm{D}$ and $5.00 \mu \mathrm{g} \mathrm{l}^{-1}$ TDZ had the highest averages (57.5 and 52.5\%, respectively), at 52 days old. (Table 3)
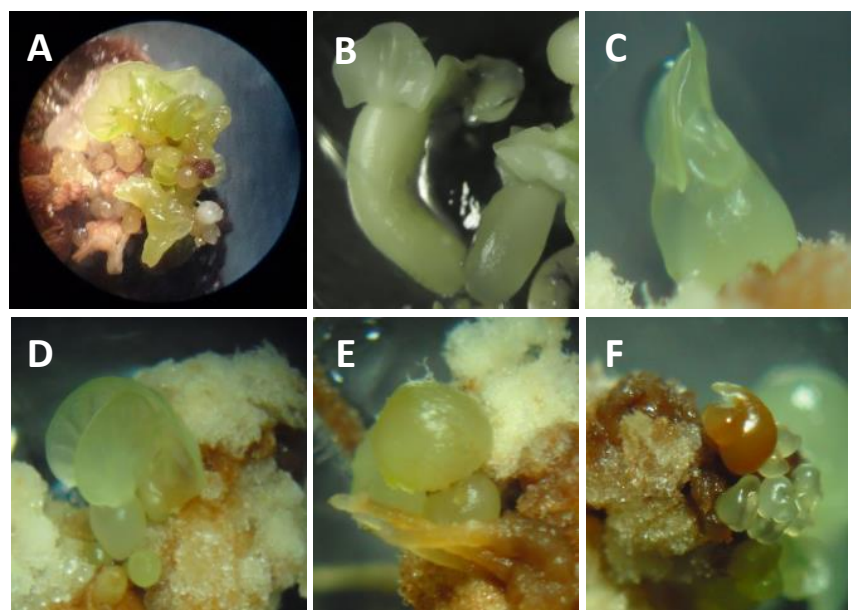

Figure 1: Embryogenic expression in genotypes, ICT-1189 (A), ICT-2142 (B), ICT-1087 (C), ICT$2161(D), I C T-1092(E)$ and ICT-1292 (F).

The results reported in the present study are in concordance with Li et al [16]; the authors studied different concentrations of TDZ to induce somatic embryogenesis in cacao genotypes, where $22.7 \mathrm{nM}$ or $5 \mu \mathrm{g} \mathrm{l}^{-1}$ where sufficient to produce optimal production of somatic embryos from staminodes. The 2.4 Diclorofenoxiacetico, is condisered as the main factor of induction to somatic embryogenesis [17]. Jimenez [18], reports that adding $2.4 \mathrm{D}$ to the media culture could increase the endogen hormone levels in the explants, resulting in the embryogenic response.

\section{Conclusions}

Based in the results ICT-2161 and ICT2142 showed the highest responses to treatments. All the combinations of genotypes and hormones formed calli, where ICT-1087 and ICT-1187 had the highest averages. Four type of calli (Fine crystalline, thick crystalline, semi-compact and compact) were observed. Furthermore, a clear organogenic response was observed due the roots formation from calli.

\section{Acknowledgments}

To the Programa Nacional de Innovacion para la Competividad y Productividad- Innóvate Perú for the financial support of the research, Contract $\mathrm{N}^{\circ}$ 195-FINCYT-IA-2013. To the researchers of the technical team of the Instituto de Cultivos Tropicales - ICT, for the confidence offered.

\section{How to Cite this Article:}

M. A. Garate-Navarro and E. Arévalo-Gardini, "Induction of Somatic Embryogenesis from Cocoa Farmer Field Collection of ICT - Peru", International Annals of Science, vol. 2, no. 1, pp. 6-11, 2017.

doi: 10.21467/ias.2.1.6-11

\section{References}

[1] R.J. Hunter, The status of cocoa (Theobroma cacao, Sterculiaceae) in the western hemisphere. Econ Bot 44:425-439. 1990

[2] A.I. Urrea-Trujillo, L. Atehortúa-Garcés, A.M. GallegoRúa, Regeneration through somatic embryogenesis of an elite colombian Theobroma cacao L. variety. Rev. Colomb. Biotecnol. 13 (2): 39-50. 2011.

[3] S.N. Maximova, L. Alemano, A. Young, N. Ferriere, A. Traore, M.J. Guiltinan, Efficiency, genotypic variability, and celular origin of primary and scecondary somatic embryogenesis of Theobroma cacao L. In Vitro Cellular and Developmental Biology - Plant, v.38, p. 252-259. 2002

[4] A. Chávez, and J. Mansilla, Manual del cultivo de cacao. Perú: Ministerio de Agricultura, Programa para el Desarrollo de la Amazonia. pp. 100. 2004

[5] J. Silva, S. Montes, L. Acosta, E. Arias and A. García, Embriogénesis Somática una alternativa para la Propagación, Mejoramiento y Conservación de Germoplasma en Cacao. Cuba 9-12 pp. 2006

[6] M.J. Guiltinan, S.N. Maximova, College of Agricultural Sciences. Integrated System for Vegetative Propagation of Cacao. Protocol Book. Pennsylvania State University. Version 2.1 4-24pp. 2010

[7] D. Driver and D. Kuniyuki, In vitro propagation of Paradox walnut rootstock. HortScience, 19: 507-509. 1984

[8] G. Lloyd and B. Mc Cown, Woody Plant Medium: A mineral nutrient formulation for microculture of woody plant species. HortScience, 16: 453. 1981

[9] J.A. Di Rienzo, F. Casanoves, M.G. Balzarini, L. Gonzalez, M. Tablada and C.W. Robledo, InfoStat versión 2014. Grupo InfoStat, FCA, Universidad Nacional de Córdoba, Argentina. URL http://www.infostat.com.ar. 2014

[10] B. Quimbita, Efecto de la concentración de 2,4-D y el tipo de explante en la formación de callos embriogénicos en el cultivo in vitro de cacao (Theobroma cacao L.). Trabajo de diploma. Universidad de Granma. Facultad de Ciencias Agrícolas -Centro de Estudios de Biotecnología Vegetal. Bayamo, CU. pp. 33-43. 2011

[11] C. Chanatásig, "Inducción de la embriogénesis somática en clones superiores de cacao (Theobroma cacao L.), con resistencia a enfermedades fungosas". Thesis. CATIE, Turrialba, Costa Rica. 2004 
[12] G.F. Santana, R.Velásquez and J. Mata, Carbon source effect on cacao organogenesis and somatic embryogenesis. Citogenetic analysis. Agronomía Trop. 60 (2). 12p 2010

[13] K. Díaz, C. Valiente, M. Martínez, M. Castillo and E. Sanfuentes, Root-promoting rhizobacteria in Eucalyptus globulus cuttings. World Journal of Microbiology and Biotechnology, v. 25, n. 5, p. 867-873, 2009.

[14] L. Monsalve, C. García and A. Sigarroa, Obtención de embriones somáticos primarios de Theobroma cacao en clones de interés regional para el departamento Norte de Santander, Colombia. Revista Respuestas, 1: 21-28. 2005

[15] C. Tan and D. Furtek, Development of an in vitro regeneration system for Theobroma cacao from mature tissues. Plant Science, 164: 407-412. 2003

[16] Z. Li, A. Traore, S.N. Maximova, M.J. Guiltinan, Somatic embryogenesis and plant regeneration from Floral explants of cacao (Theobroma cacao L.) using thidiazuron. In Vitro Cell Dev Biol Plant 34:293-299pp. 1998

[17] P.V. Ammirato, Embryogenesis. In: D.A. Evans, W.R. Sharp, P.V. Ammirato and Y. Yamada, Handbook of plant cell culture, V. I. Kluwer Academic Publisher, Dordreh, p. 81-181. 1993

[18] V. Jiménez, Involvement of plant hormones and plant growth regulators on in vitro somatic embryogenesis. Plant Growth Regulation 47:91-110. 2005
Publish your research article in AIJR journals-

$\checkmark$ Online Submission and Tracking

$\checkmark$ Peer-Reviewed

$\checkmark \quad$ Rapid decision

$\checkmark \quad$ Immediate Publication after acceptance

$\checkmark \quad$ Articles freely available online

$\checkmark \quad$ Retain full copyright of your article.

Submit your article at journals.aijr.in

Publish your books with AIJR publisher-

$\checkmark \quad$ Publish with ISBN and DOI.

$\checkmark$ Publish Thesis/Dissertation as Monograph.

$\checkmark$ Publish Book Monograph.

$\checkmark$ Publish Edited Volume/ Book.

$\checkmark$ Publish Conference Proceedings

$\checkmark \quad$ Retain full copyright of your books.

Submit your manuscript at books.aijr.org 